\title{
Evaluating Sweet Onion Cultivars for Sugar Concentrations and Pungency
}

Charles S. Vavrina

Southwest Florida Research and Education Center, University of Florida, P.O. Drawer 5127, Immokalee, FL 33934

Doyle A. Smittle Coastal Plain Experiment Station, University of Georgia, Tifton, GA 31793

Additional index words. Allium cepa, Granex onions, Grano onions

Abstract. Six onion (Allium cepa $\mathbf{L}$.) cultivars were grown during 2 years to evaluate the effects of environment on bulb quality as measured by sugar and pyruvate (pungency) concentrations. Within each year, bulb fresh weight was not affected by cultivar; however, bulb fresh weights were $36 \%$ higher in a year when most of the rain fell during maximum bulb expansion. Total bulb sugar concentration and pungency varied among cultivars and years. Pungency was higher and the sugar: pungency ratio was lower in 'Texas 1015Y' and 'Sweet Georgia' than in 'Dessex', 'Rio Bravo','Hybrid Yellow Granex', and 'Granex 33'. Under low $S$ nutrition, market acceptance of "sweet" onion cultivars that vary slightly in nonstructural water-soluble carbohydrates may be assessed more precisely by the sugar : pungency ratio than by sugar or pungency assessments.

Onions grown for the "sweet" onion market in the United States have an annual farm value of $>\$ 100$ million. Consumers often iden-

Received for publication 18 May 1992. Accepted for publication 19 Mar, 1993. Florida Agricultural Experiment Station Journal Series no. 9965. The cost of publishing this paper was defrayed in part by the payment of page charges. Under postal regulations, this paper therefore must be hereby marked advertisement solely to indicate this fact. tify an onion's pungency or sweetness based on regional names such as "Vidalia" or "Wallawalla." Even with consistent cultural practices, however, onion pungency can vary from year to year.

Ontogeny and environmental and cultural factors affect onion pungency. Platenius and Knott (1934) determined that cultivar had the most pronounced influence on onion pungency; however, temperature, relative humid- ity, and hours of sunlight also modified pungency within a cultivar. Platenius and Knott (1935) and Saghir et al. (1965) noted that growth stage was important when sampling for pungency. Soil type and irrigation can affect onion pungency (Platenius, 1941). Freeman and Mossadeghi (1973) demonstrated that water stress enhanced onion pungency.

The sulfate concentration of growth medium influenced flavor strength in onions (Freeman and Mossadeghi, 1970). Applying S in the field increased the pungency of short-day onions; however, increasing soil sulfate concentration may or may not increase onion yield (Freeman and Mossadeghi, 1970; Granberry et al., 1989; Patterson, 1979; Smittle, 1984).

Randle (1992a) found that S nutrition affected the concentration of total and individual nonstructural water-soluble carbohydrates (NWSCs) in 60 onion plant introductions or accessions. He suggested that the soil $\mathrm{S}$ concentration in onion production areas should be considered when selecting for sugar concentration in onions. However, sugar and pungency levels of market-proven, short-day onion cultivars have not yet been established.

The objective of this study was to assay short-day Granex- and Grano-type onion cultivars for several bulb quality factors, including sugar concentration, pungency, and yield. The study was conducted over 2 years under similar $\mathrm{S}$ nutrition to assess environmental effects on yield and flavor.

Five Granex-type onion cultivars were included in the study: 'Dessex', 'Granex 33', 'Hybrid Yellow Granex', 'Rio Bravo', and 
'Sweet Georgia'. Grano-type 'Texas 1015Y' was tested for comparison. Granex onions (flattened, globe-shaped bulb) are used in most "sweet" onion production areas, whereas the Grano onion (top-shaped) is used mostly in Texas.

Transplants to be used bare-rooted were grown on raised beds spaced $2 \mathrm{~m}$ apart. Seeds were planted $8 \mathrm{~mm}$ apart $(988,400 \mathrm{seeds} / \mathrm{ha})$ in a twin-line triangular pattern using a mechanical seeder (model 78; John Deere, Moline, Ill.). Beds were $93 \mathrm{~cm}$ wide with $15 \mathrm{~cm}$ between rows. Irrigation and pesticides were applied as needed. When transplant stem diameter was 6 to $8 \mathrm{~mm}$ (in $\approx 10$ weeks), the transplants were undercut, bundled according to cultivar, and transported to the test site. The same test site was used both years.

Seedlings were transplanted by hand into raised beds of Tifton fine loamy sand soil (fine-loamy, siliceous, thermic, Plinthic Paleudult) during the second week of Jan. 1987 and 1988. Rows were $36 \mathrm{~cm}$ apart with $13 \mathrm{~cm}$ between plants. This spacing resulted in four rows of plants per $1.8-\mathrm{m}$ wide bed. Plots were $0.9 \times 6.2 \mathrm{~m}$ with two cultivars per bed. Cultivars were arranged in a randomized complete-block design with four replications.

A total of $224 \mathrm{~kg} \cdot \mathrm{ha}^{-1}$ of $10 \mathrm{~N}-8.3 \mathrm{P} 4.4 \mathrm{~K}-$ $5 \mathrm{~S}$ was applied each year in four equal applications, at planting, and then at 30-day intervals until 2 weeks before harvest. About $19 \mathrm{~kg}$ S/ha was added via the irrigation water. Cultural practices, other than fertilization, were according to Univ. of Georgia Extension Service recommendations (Vavrina and Granberry, 1988) during both years.

Mature bulbs were hand-harvested when $50 \%$ of the foliage in each plot had lodged. Tops and roots were removed from the bulbs. The bulbs were field-cured in burlap bags for 3 days in full sun. Bulbs were graded into three diameter classes: $>7.6 \mathrm{~cm},>6.4 \mathrm{~cm}$, and $>5.1$ $\mathrm{cm}$ in diameter. Bulb count and total fresh weight in each class were recorded. A subsample of 10 bulbs from each size class from each cultivar from each replication was selected for analysis of sugars and pungent $y$. Analysis was performed within 3 weeks of harvest.

Onion pungency was estimated by the pyruvic acid development (PAD) method of Schwimmer and Weston (1961), as modified by Smittle et al. (1979) and Smittle (1988). The PAD method estimates onion pungency as equimolar concentrations of pyruvic acid, ammonia. and the volatile $\mathrm{S}$ compound that produces the lachrymose reaction of pungency and flavor in onions. These compounds are formed by the enzymatic hydrolysis of the nonpungent precursor, predominantly \$(1- propenyl) L-cysteine sulfoxide, when tissue integrity is destroyed. A close relationship between PAD and the sensory evaluation of pungency has been established (Wall, 1992).

Bulb sugar concentrations (sucrose, glucose, and fructose) were measured by high performance liquid chromatography, as described by Smittle and Maw ( 1988). Data were subjected to analysis of variance and mean separation by Duncan's multiple range test.
Bulb fresh weight was influenced by year $(P \leq 0.01)$, not by cultivar or the cultivar $\times$ year interaction. In 1987, mean total bulb fresh weight was $31.7 \mathrm{t} \cdot \mathrm{ha}^{-1}$, compared to $45.7 \mathrm{t} \cdot \mathrm{ha}^{-1}$ in 1988. Similarly, more "jumbo" bulbs (>7.6 $\mathrm{cm}$ in diameter) were produced in $1988(79 \%$ by number) than in 1987 (34\%). The lower yield in 1987 was attributed to retarded plant establishment and earl y bulb growth resulting from heavy rainfall in January and March (Table 1).

Bulb percentage dry weight was highest in 'Sweet Georgia' and 'Rio Bravo' and lowest in 'Texas 1015 Y', 'Granex 33', and 'Dessex' (Table 2). While Smittle et al. (1979) correlated increased dry weight with greater storage life in onions, the literature on this subject shows inconsistencies in such correlations (Rutherford and Whittle, 1984; Suzuki and Cutcliffe, 1989).

Bulb sucrose concentration and percentage dry weight paralleled each other by cultivar (Table 2). Bulb sucrose concentration was highest in 'Sweet Georgia' and lowest in 'Texas 1015 Y'. Bulb glucose concentration ranged from $3.77 \%$ in 'Dessex' to 3.017. in 'Granex 33'. Fructose concentration was lowest in 'Hybrid Yellow Granex' bulbs. The approximate ratio of 1 sucrose: 2 fructose: 3 glucose concentrations in these cultivars was similar to that previously reported for short-day commercial onions (Smittle, 1988; Smittle and Maw, 1988; Randle, 1992a).

Higher sucrose concentrations in 1987 than in $1988(1.08 \%$ vs. $0.76 \%)$ possibly were associated with a greater accumulation of rain during early 1987 (January to March), an event that may have leached more $S$ from plots. Although no temporal relationship between $S$ uptake and bulb pungency has been established, Randle (1992a) showed that 'Granex 33' bulbs accumulated more sucrose, glucose, and fructose when grown with low than with high $\mathrm{S}$ nutrition. Concentrations of glucose, fructose (Table 2), and total sugars (Table 3) were not affected by production year. 'Dessex' contained the highest $(7.39 \%)$ while 'Granex 33' contained the lowest total sugar concentration $(6.02 \%)$. Of the cultivars Randle (1992a) assayed, 'Granex 33' was among those with the lowest total sugar concentration.

'Texas 1015Y' and' Sweet Georgia' were the most pungent cultivars, and 'Hybrid Yellow Granex' was the least pungent (Table 3). Overall, bulbs produced in $1987(\mathrm{PAD}=2.13)$ were less pungent than those produced in 1988 $(\mathrm{PAD}=3.42)$. The significant year $\times$ cultivar interaction was due to the large increase in pungency of some cultivars. 'Rio Bravo' showed the largest increase in pungency, with PAD increasing from 1.9 in 1987 to $4.2 \mu \mathrm{mol} \cdot \mathrm{g}^{-1}$ fresh weight in 1988. 'Sweet Georgia', 'Texas 1015Y', and 'Hybrid Yellow Granex' PADs were $1.25,1.18$, and $1.05 \mu \mathrm{mol} \cdot \mathrm{g}^{-1}$ fresh weight higher in 1988 than in 1987, while 'Dessex' and 'Granex 33' showed PAD increases of only 0.34 and $0.55 \mu \mathrm{mol} \cdot \mathrm{g}^{-1}$ fresh weight, respectively. Randle (1992b) also found changes in pungency were greater in some onion cultivars under differing cultural systems. Although cultivar pungency changed

Table 1. Environmental conditions during the onion-mowing season, 1987 and $1988{ }^{2}$

\begin{tabular}{lcccc}
\hline \hline \multirow{2}{*}{ Month } & \multicolumn{2}{c}{ Air temp $\left({ }^{\circ} \mathrm{C}\right)$} & $\begin{array}{c}\text { Rainfall } \\
(\mathrm{mm})\end{array}$ & $\begin{array}{c}\text { Soil temp } \\
\text { ("c) }\end{array}$ \\
\cline { 2 - 4 } & $\operatorname{Max}$ & Min & & \\
January & & 1987 & 96 & 10.2 \\
February & 13.2 & 3.3 & 44 & 10.8 \\
March & 14.3 & 4.4 & 81 & 17.0 \\
April & 19.5 & 8.2 & 15 & 18.4 \\
& 24.3 & 10.2 & & \\
January & & 1988 & 53 & 7.9 \\
February & 10.7 & 0.5 & 58 & 1.0 \\
March & 16.4 & 1.8 & 34 & 14.6 \\
April & 21.0 & 4.8 & 115 & 19.4 \\
\hline
\end{tabular}

${ }^{2}$ Claxton, Ga. (U.S. Dept. of Agriculture-approved) weather station was located $\approx 56 \mathrm{~km}$ from the test site.

"Air temperature $1.5 \mathrm{~m}$ above soil surface.

Soil temperature $10.2 \mathrm{~cm}$ below soil surface.

Table 2. Bulb dry weight as a percentage of fresh weight and concentrations of sucrose, glucose, and fructose averaged over years in several onion cultivars.

\begin{tabular}{lcccc}
\hline \hline & Bulb dry & \multicolumn{3}{c}{ Sugar concn (\% fresh wt) } \\
\cline { 3 - 5 } Cultivar & $\mathrm{wt}^{2}(\%)$ & Sucrose & Glucose & Fructose \\
\hline Sweet Georgia & $9.13 \mathrm{a}^{y}$ & $1.25 \mathrm{a}$ & $3.12 \mathrm{C}$ & $2.60 \mathrm{a}$ \\
Rio Bravo & $8.85 \mathrm{ab}$ & $0.98 \mathrm{~b}$ & $3.42 \mathrm{a}-\mathrm{c}$ & $2.61 \mathrm{a}$ \\
Hybrid Yellow Granex & $8.51 \mathrm{bc}$ & $0.99 \mathrm{~b}$ & $3.61 \mathrm{ab}$ & $1.93 \mathrm{c}$ \\
Dessex & $8.09 \mathrm{~cd}$ & $0.96 \mathrm{~b}$ & $3.77 \mathrm{a}$ & $2.66 \mathrm{a}$ \\
Granex 33 & $7.91 \mathrm{~d}$ & $0.83 \mathrm{~b}$ & $3.01 \mathrm{c}$ & $2.18 \mathrm{bc}$ \\
Texas 1015Y & $7.62 \mathrm{~d}$ & $0.45 \mathrm{c}$ & $3.14 \mathrm{bc}$ & $2.44 \mathrm{ab}$ \\
Significance & $* *$ & $* *$ & & \\
Year (Y) & $* *$ & $* *$ & NS & NS \\
Cultivar $(\mathrm{C})$ & NS & NS & NS & NS \\
Y $\times$ C & & & &
\end{tabular}

${ }^{2}$ Grams per 100 grams fresh weight.

'Mean separation in columns by Duncan's multiple range test, $P \leq 0.05$.

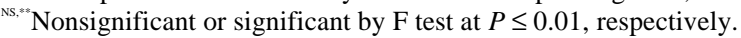


Table 3. Total sugar concentration, pungency, and sugar: pungency ratio averaged over years as influenced by cultivar.

\begin{tabular}{lccc}
\hline \hline Cultivar & $\begin{array}{c}\text { Total sugar } \\
(\%)\end{array}$ & Pungency & $\begin{array}{c}\text { sugar : } \\
\text { pungency }\end{array}$ \\
\hline Hybrid Yellow Granex & $6.53 \mathrm{bc}^{\mathrm{x}}$ & $2.22 \mathrm{c}$ & $2.93 \mathrm{a}$ \\
Dessex & $7.39 \mathrm{a}$ & $2.63 \mathrm{bc}$ & $2.81 \mathrm{ab}$ \\
Rio Bravo & $7.01 \mathrm{ab}$ & $2.76 \mathrm{~b}$ & $2.53 \mathrm{a}-\mathrm{c}$ \\
Granex 33 & $6.02 \mathrm{C}$ & $2.63 \mathrm{bc}$ & $2.29 \mathrm{bc}$ \\
Sweet Georgia & $6.97 \mathrm{ab}$ & $3.30 \mathrm{a}$ & $2.11 \mathrm{~cd}$ \\
Texas 1015Y & $6.03 \mathrm{C}$ & $3.47 \mathrm{a}$ & $1.74 \mathrm{~d}$ \\
Significance & & $* *$ & $* *$ \\
Year (Y) & NS & $* *$ & $* *$ \\
Cultivar (c) & $* *$ & $* *$ & $\mathrm{NS}$ \\
Y $\times$ C & $\mathrm{NS}$ & & \\
\hline
\end{tabular}

${ }^{2}$ Total sugars measured (fresh weight basis) as sucrose, glucose, and fructose.

'Pungency expressed as pyruvic acid development (micromoles per gram of fresh tissue).

'Mean separation in columns by Duncan's multiple range test, $P \leq 0.05$.

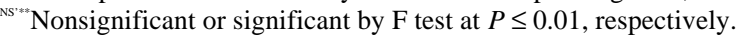

during the 2-year evaluation, 'Texas $1015 \mathrm{Y}$ ' was the most pungent cultivar both years.

The sugar: pungency ratio differed among the Granex-type cultivars (Table 3). 'Hybrid Yellow Granex' had the highest sugar : pungency ratio and 'Sweet Georgia' had the lowest. The sugar : pungency ratio of 'Texas 1015Y' was lower than that of four Granex cultivars but not different from that of' Sweet Georgia'. The greater sugar: pungency ratio in 1987 (2.93) vs. 1988 (2.06), even though cultural regimes were similar, resulted from less pungency and more sugar in the onions produced in 1987 than in 1988.

Exactly when pungency during bulb ontogeny dominates the organoleptic experience has yet to be determined however, quality in mild, short-day onions has been associated with low pungency and high sugar (Smittle, 1988). Wall established a relationship between PAD and sensory evaluation of pungency. Therefore, the sugar : pungency ratio may provide a better indication of organoleptic quality than either sugar or pungency alone. At present, this ratio approach may be more valid for "sweet" onions than onions for dehydration, which are bred for high carbohydrates and extreme pungency (Derbyshire and Henry, 1979). However, a relationship between the sugar : pungency ratio and the organoleptic experience has yet to be determined.

Although cultural practices may be followed rigidly in producing onions from year to year, cultivar and environment play major roles in onion pungency and sugar concentra- tions. Randle (1992a) showed that S nutrition affected onion NWSCs, while Derbyshire and Henry (1979) showed that onion cultivars differ in NWSC concentration and composition. The present results, in which year affected bulb sugar concentration and pungency, support the observations of Platenius and Knott (1934) that environmental factors affect onion sweetness.

Under conditions of low S nutrition, market acceptance of "sweet" onion cultivars that vary slightly in NWSC may be assayed more precisely by the sugar : pungency ratio. This determination may separate the effect of sugar accumulation from the masking effect of pungency, providing a more realistic taste measure of "sweetness." 'Hybrid Yellow Granex', 'Dessex', and 'Rio Bravo' seem to maintain high sugar : pungency ratios consistently under varying environmental conditions. Conversely, 'Texas $1015 \mathrm{Y}$ ' had the lowest sugar: pungency ratio in both years, regardless of environment. Such plant responses should be considered when selecting onion cultivars to produce high-quality sweet onions.

\section{Literature Cited}

Derbyshire, B. and R.J. Henry. 1979. The association of fructans with high percentage dry weight in onion cultivars suitable for dehydration. J. Sci. Food Agr. 30:1035-1038

Freeman, G.G. and N. Mossadeghi. 1970. Effect of sulphate nutrition on flavor components of onion (Allium cepa). J. Sci. Food Agr. 21:610615.
Freeman, G.G. and N. Mossadeghi. 1973. Studies on the relationship between water regime and flavor strength in watercress (Rorippa nasturium-aquaticum (L.) Hayek), cabbage (Brassica oleracea capitata) and onion (Allium сера). J. Hort. Sci. 48:365-378.

Granberry, D.M., W.J. McLaurin, and D. Smittle. 1989. The effects of calcium sulfate on growth and yield of Granex 33 "Vidalia type" onion. Proc. Natl. Onion Res. Conf., Boise, Idaho. p. 12-18.

Patterson, D.R. 1979. Sulfur fertilization effects on yield and pungency. Texas Agr. Expt. Sta. Prog. Rpt. 3551:1-2.

Platenius, H. 1941. Factors affecting onion pungency. J.Agr.Res.62:371-379.

Platenius, H. and J.E. Knott. 1934. Pungency of onions in relation to variety and ecological factors. Proc. Amer. Soc. Hort. Sci. 32:593-595.

Platenius, H. and J.E. Knott. 1935. The pungency of the onion bulb as influenced by the stage of development of the plant. Proc. Amer. Soc. Hort. Sci. 33:481-483.

Randle, W.M. 1992a. Sulfur nutrition affects nonstructural water-soluble carbohydrates in onion germplasm. HortScience 27:52-54.

Randle, W.M. 1992b. Sampling procedures to estimate flavor potential in onion. HortScience 27:1116-1117.

Rutherford, P.P. and R. Whittle. 1984. Methods of predicting the long-term storage of onions. J. Hort. Sci. 59:537-543.

Saghir, A. R., L.K. Mann, and M. Yamaguchi. 1965. Composition of volatiles in Allium as related to habitat, stage of growth, and plant part. Plant Physiol. 35:681-685.

Schwimmer, S. and W.J. Weston. 1961. Enzymatic development of pyruvic acid as a measure of pungency. J. Agr. Food Chem. 9:301-304.

Smittle, D.A. 1984. Responses of onions to sulfur and nitrogen fertilization. Georgia Agr. Expt. Sta. Res. Rpt. 455.

Smittle, D.A. 1988. Evaluation of onion storage methods. J. Amer. Soc. Hort. Soc. 113:877-880.

Smittle, D.A., M.J. Hayes, and W.L. Dickens. 1979 Quality evaluation of onion. Georgia Agr. Expt. Sta. Res. Rpt. 336.

Smittle, D.A. and B. Maw. 1988. Effects of maturity and harvest methods on storage and quality of onions. HortScience 23:141-143.

Suzuki, M. and J.A. Cutcliffe. 1989. Fructans in onion bulbs in relation to storage life. Can. J. Plant Sci. Rev. Can. Phytotechnol. 69:13271333

Vavrina, C.S. and D. Granberry. 1988. Commercial vegetable production: Dry bulb onions. Georgia Coop. Ext. Circ. 801

Wall, M. 1992. A reliable method for evaluating onion pungency. Onion World 8: 19-20. 